\title{
Applications of the Green Synthesized Gold Nanoparticles-Antimicrobial Activity, Water Purification System and Drug Delivery System
}

\author{
Kamala Priya M.R*, Priya R. Iyer \\ Department of Biotechnology, Women's Christian College, College Road, Chennai- 600006, Tamil Nadu, India
}

\begin{abstract}
Received: May 14, 2015; Accepted: June 21, 2015; Published: August 21, 2015
*Corresponding author: Kamala Priya MR, Department of Biotechnology, Women's Christian College, College Road, Chennai- 600006, Tamil Nadu, India, E-mail: brajuraj@yahoo.com
\end{abstract}

\begin{abstract}
It has been previously stated that gold nanoparticles have been successfully synthesized using various green extracts of plants [14]. The synthesized gold nanoparticles were characterized under SEM and EDX to identify the size of the nanoparticles $[5,6]$. It was found that the nanoparticles were around $30 \mathrm{~nm}$ in size, which is a commendable nano dimension achieved through a plant mediated synthesis [7-9]. The nanoparticles were further studied for their various applications like anti-microbial efficiency, [10] fabrication of gold nanoparticles in the filter paper and role in water purification, anticoagulant ability, MIC studies against microbial cells, drug loading and in vitro drug release [11]. And, we have made attempts to exploit the anticancer ability of the gold nanoparticles. The nanoparticles were studied against MCF 7 breast cancer cell lines and proved to be efficient with anticancer properties against the cell lines $[12,13]$. The nanoparticles yielded positive results in all the above-mentioned studies, thereby concluding that the nanoparticles can be extensively applied into various fields of interest and study.
\end{abstract}

\section{Abbreviations}

SEM: Scanning Electron Microscope; EDS: Energy Dispersive X-ray Spectroscopy; MIC: Minimum Inhibitory Concentration

\section{Introduction}

This integration of nanoparticles with biological molecules has lead to the development of diagnostic devices, contrast agents, and important tools in cancer therapy. Nanobiotechnology describes an application of biological systems for the production of new functional material such as nanoparticles. Currently, there are many gold nanoparticles industrial uses that resulted in its demand and production. Recent advancement in technology has introduced gold nanoparticles into the medical field. As studies of gold nanoparticles improve, several gold nanoparticles medical applications have been developed to help and prevent the onset of infection and promote faster wound healing. The targeted drug delivery is one recent gold nanoparticles used in medical application of study.

\section{Applications ofthe Synthesized Gold Nanoparticles Materials and methods}

Antibacterial efficacy by well diffusion method: The materials required were LB agar medium, bacterial culture, Petri plates and a cotton swab. The LB agar medium was poured into Petri plates and allowed to solidify. The inoculum was mixed in saline. The cotton swab was dipped in the saline and was streaked onto the plate. 4 wells around $10 \mathrm{~mm}$ were cut out aseptically with the help of a cork borer. The wells were filled with $50 \mu \mathrm{l}$ of the synthesized nanoparticles. The plates were incubated at $37^{\circ} \mathrm{C}$ for $24 \mathrm{hrs}$.

Fabricating gold nanoparticles in filter paper: The materials required were Whatman Filter paper and synthesized Gold nanoparticles. The filter paper was soaked in nanoparticles solution for about 30 mins. The paper was allowed for drying. Then the coated and non-coated filter paper was used to filter tap water. The filtered water was used for plating. The plates were incubated at $37^{\circ} \mathrm{C}$ for $24 \mathrm{hrs}$. Following day, the plates were noted for the number of colonies of bacteria grown.

Anticoagulant ability: The materials required were Lancet, Ethanol, Cotton and a Glass slides. The finger was wiped with ethanol, pierced and two drops of blood was kept on glass slide. One was used as a control and other with the test sample, kept for $1 \mathrm{~min}$ and observed for the change.

Drug loading: $50 \mu \mathrm{l}$ of peptide protein drug insulin (Human Mixtard 40) was incubated with $200 \mu \mathrm{l}$ of synthesized gold nanoparticle solutions and kept in stirring for different time periods such has $6 \mathrm{hrs}, 12 \mathrm{hrs}$ and $24 \mathrm{hrs}$. After the incubation time, the unbound drug was removed by centrifugation at $18,000 \mathrm{rpm}$ for $20 \mathrm{~min}$. The unbound drug in the supernatant solution was quantified using UV-visible spectrophotometer. The percentage of entrapment efficiency was calculated from the formula,

$\%$ Entrapment efficiency $=\frac{\text { Total amount of drug }- \text { Amount of drug in supernatant } \times 100}{\text { Total amount of the drug }}$ 
In vitro drug release: To study the in vitro drug release pattern, the peptide protein drug-loaded gold nanoparticles were incubated in PBS buffer, $\mathrm{pH} 7.4$ at $37^{\circ} \mathrm{C}$ in microcentrifuge tube and stirred at $100 \mathrm{rpm}$. At selected time intervals, the sample was taken and replaced with fresh PBS buffer of $\mathrm{pH}$ 7.4. The drug content was quantified by using UV visible spectrophotometer by comparing with a standard curve.

\section{Minimum Inhibitory Concentration (MIC) \\ Principle}

This procedure is performed to identify the minimum inhibitory concentration of nanoparticles that has the ability to inhibit the growth of the particular bacterium. It is denoted by low OD values from which the percentage of inhibition and viability of organism can be calculated. If any OD corresponds to $100 \%$ inhibition and $0 \%$ viability, that particular concentration is termed as the MIC for that organism.

\section{Materials and Methods}

The materials required were Microtiter plate, Sterile RPMI broth, synthesized gold nanoparticles and overnight grown cultures. The first 2 columns of the titer plate were considered as the 'blank' and 'control'. The 'blank' wells had media and nanoparticles and the 'control' wells had media and culture. After the addition of the media, nanoparticles and culture to the wells, the plate was incubated at $37^{\circ} \mathrm{C}$ for 24 hours. The titer plate was taken out the next day and the OD was recorded for all the wells using a plate reader. The readings were exported to an excel file and the percentage of inhibition was calculated using the formula below,

$\% \mathrm{I}=($ Absorbance of control -Absorbance of treated cells $) \times 100$

(Absorbance of control)

\section{Results and Discussion}

\section{Antibacterial efficacy by well diffusion method}

The results show that the gold nanoparticles possess good antimicrobial activity against the various strains of bacteria tested and imply that these nanoparticles can be further exploited on their antibacterial efficacy against a wide spectrum of microorganisms. It has been stated in various studies that silver has good antimicrobial activity including Sukdeb, et al. [14] and so we have tested it for gold nanoparticles. N- Nanoparticles, PPositive control (Antibiotic), C- Control (without Nanoparticles), E- Plant extract. (Figure 1) (Table 1).

\section{Fabricating gold nanoparticles in filter paper}

The difference in the number of colonies between water filtered through nanoparticles fabricated filter paper and nonfabricated filter paper (Table 2).

There is a distinctive reduction in the number of colonies after filtering through blotting paper incorporated with gold nanoparticles. It can be viewed from the above figures that the nanoparticles have been trapped inside the filter paper. In U.S. Environmental Protection Agency, it has been approved for the use of silver nanoparticles coated with PVP foams for filtering potable water. With this background, we have studied with gold nanoparticles in the process of purification of potable water. And based on the above results, gold nanoparticles can be exploited for the development of a novel water purification system (figure 2).

\section{Anticoagulant ability}

Figure 3 shows that the nanoparticles help in the thinning of blood and can be further studied and used as an anticoagulant.

\section{Minimum Inhibitory Concentration Studies (MIC)}

From the above, the MIC values for each of the nanoparticle are:

\section{Drug loading}

These results indicate that the gold nanoparticles have good capabilities for intake of larger biomolecules, peptides, hormones, and other drugs. So these gold nanoparticles can be further investigated in a vast extense and employed as efficient drug delivery systems. A similar study has been reported by Ghosh, et al. [11] (Table 8).

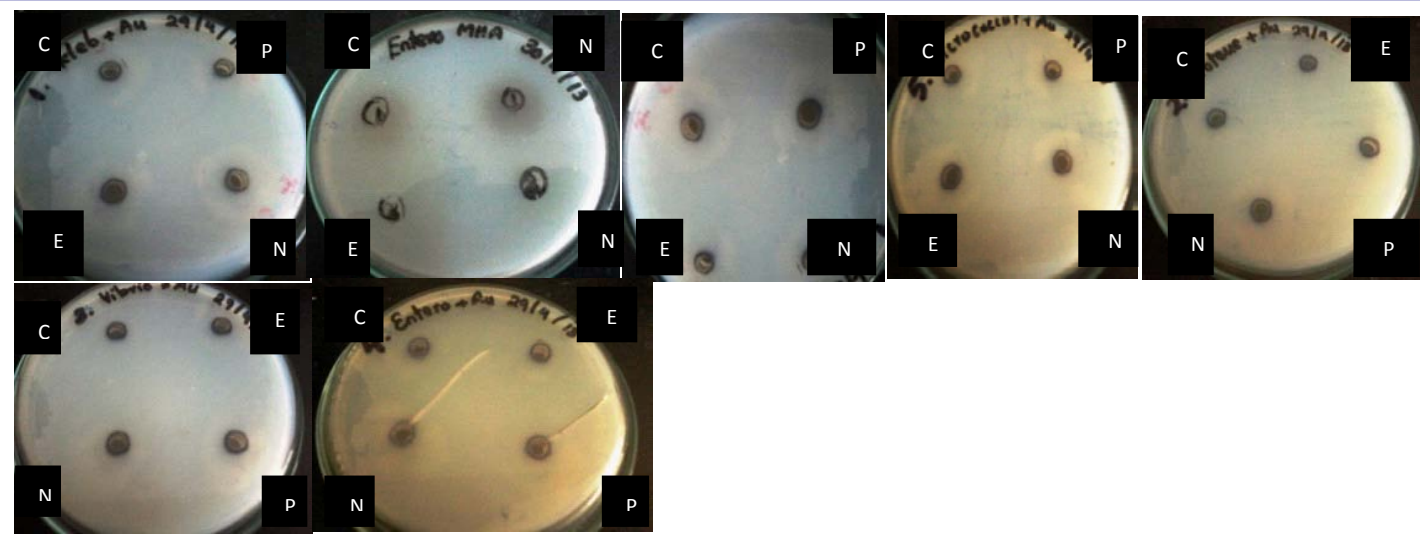

Figure 1: Shows the Strains of microorganisms tested: Klebsiella pneumoniae; Enterobacter aerogenes; Pseudomonas aeruginosa; Micrococcus luteus; Proteus vulgaris; Vibrio cholerae; Bacillus subtilis 
Table 1: Zone of inhibition of nanoparticles tested against bacterial strains.

\begin{tabular}{|l|c|c|c|c|c|c|c|}
\hline AuNP's & $\begin{array}{c}\text { Strain 1 } \\
(\mathbf{m m})\end{array}$ & Strain2 (mm) & $\begin{array}{c}\text { Strain3 } \\
\mathbf{( m m})\end{array}$ & $\begin{array}{c}\text { Strain4 } \\
\mathbf{( m m})\end{array}$ & $\begin{array}{c}\text { Strain5 } \\
\mathbf{( m m})\end{array}$ & Strain6 (mm) & Strain7 (mm) \\
\hline GTAuNP's & 22 & 21 & 25 & 17 & 22 & 24 & 19 \\
\hline ClAuNP's & 18 & - & - & 19 & - & 20 & 21 \\
\hline BTAuNP's & 20 & - & 22 & - & 20 & - & 20 \\
\hline CoAuNP's & 19 & 22 & - & - & - & 19 & 17 \\
\hline AHAuNP's & - & 20 & - & 19 & 24 & 17 & - \\
\hline MEAuNP's & 22 & - & 20 & - & 19 & 16 & - \\
\hline MAAuNP's & 17 & - & 21 & - & - & 19 & 20 \\
\hline PAAuNP's & - & 17 & - & 20 & 22 & - & 17 \\
\hline
\end{tabular}
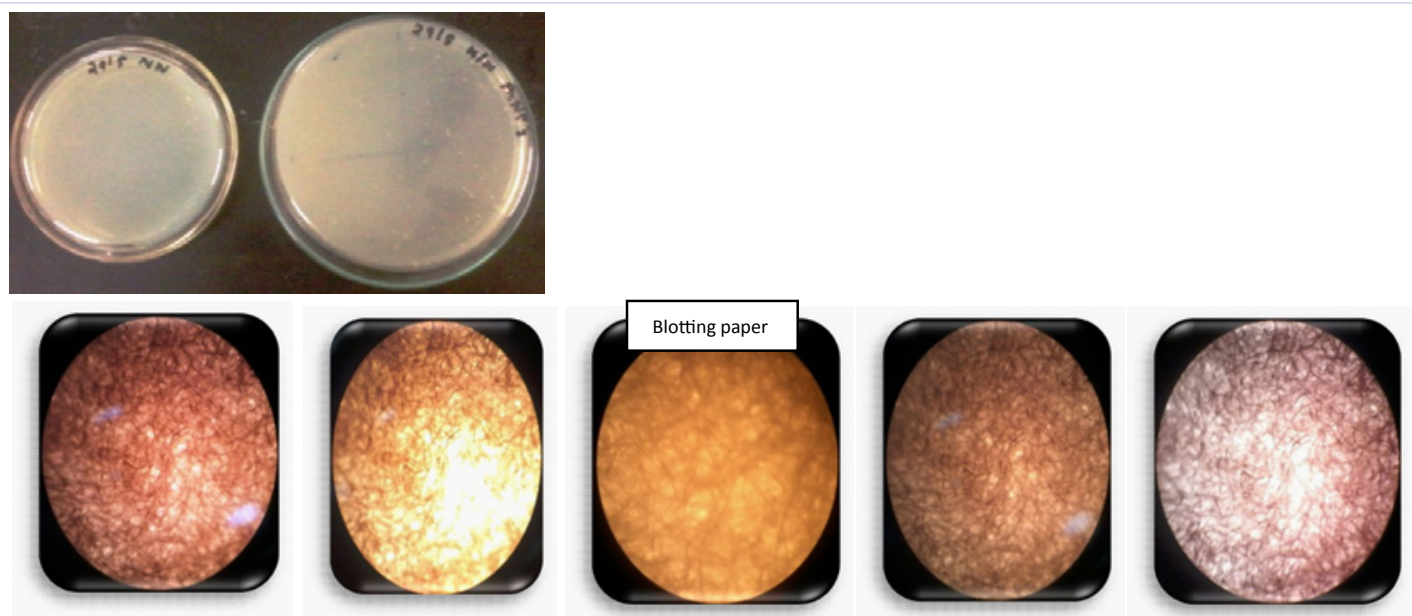

Figure 2: Blotting paper, before and after the incorporation of the AuNP's.

Table 2: \% of bacterial colonies after filtration through AuNP's fabricated filter.

\begin{tabular}{|l|l|}
\hline Samples No. of colonies & \% of colony \\
\hline Control 130 & 100 \\
\hline GTAuNP's42 & 32.3 \\
\hline ClAuNP's49 & 37.7 \\
\hline MAAuNP's52 & 40 \\
\hline CoAuNP's69 & 53.07 \\
\hline
\end{tabular}

Table 3: MIC studies of E.coli Vs 8 AuNP's.

\begin{tabular}{|l|l|}
\hline GTAuNP's & $0.9375 \mu \mathrm{g} / \mathrm{ml}$ \\
\hline ClAuNP's & $25 \mu \mathrm{g} / \mathrm{ml}$ \\
\hline BTAuNP's & $3.75 \mu \mathrm{g} / \mathrm{ml}$ \\
\hline CoAuNP's & $7.5 \mu \mathrm{g} / \mathrm{ml}$ \\
\hline AHAuNP's & $0.9375 \mu \mathrm{g} / \mathrm{ml}$ \\
\hline MEAuNP's & $3.75 \mu \mathrm{g} / \mathrm{ml}$ \\
\hline MAAuNP's & $0.46875 \mu \mathrm{g} / \mathrm{ml}$ \\
\hline PAAuNP's & $0.46875 \mu \mathrm{g} / \mathrm{ml}$ \\
\hline
\end{tabular}

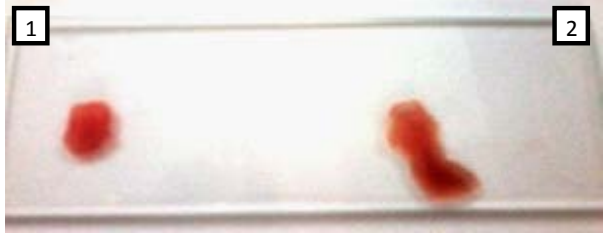

Figure 3: The difference between blood without nanoparticles (1) and blood with nanoparticles (2).

Table 4: MIC studies of S. aureus Vs 8 AuNP's.

\begin{tabular}{|l|l|}
\hline GTAuNP's & $0.9375 \mu \mathrm{g} / \mathrm{ml}$ \\
\hline ClAuNP's & $0.9375 \mu \mathrm{g} / \mathrm{ml}$ \\
\hline BTAuNP's & $12.5 \mu \mathrm{g} / \mathrm{ml}$ \\
\hline CoAuNP's & $12.5 \mu \mathrm{g} / \mathrm{ml}$ \\
\hline AHAuNP's & $0.9375 \mu \mathrm{g} / \mathrm{ml}$ \\
\hline MEAuNP's & $0.9375 \mu \mathrm{g} / \mathrm{ml}$ \\
\hline MAAuNP's & $1.875 \mu \mathrm{g} / \mathrm{ml}$ \\
\hline PAAuNP's & $0.46875 \mu \mathrm{g} / \mathrm{ml}$ \\
\hline
\end{tabular}




\begin{tabular}{|l|l|}
\hline \multicolumn{2}{|l|}{ Table 5: MIC studies of E. aerogenes Vs 8 AuNP's. } \\
\hline GTAuNP's & $50 \mu \mathrm{g} / \mathrm{ml}$ \\
\hline ClAuNP's & $3.75 \mu \mathrm{g} / \mathrm{ml}$ \\
\hline BTAuNP's & $1.875 \mu \mathrm{g} / \mathrm{ml}$ \\
\hline CoAuNP's & $3.75 \mu \mathrm{g} / \mathrm{ml}$ \\
\hline AHAuNP's & $25 \mu \mathrm{g} / \mathrm{ml}$ \\
\hline MEAuNP's & $3.75 \mu \mathrm{g} / \mathrm{ml}$ \\
\hline MAAuNP's & $1.875 \mu \mathrm{g} / \mathrm{ml}$ \\
\hline PAAuNP's & $1.875 \mu \mathrm{g} / \mathrm{ml}$ \\
\hline
\end{tabular}

Table 6: MIC studies of $P$. vulgaris Vs 8 AuNP's.

\begin{tabular}{|l|l|}
\hline GTAuNP's & $0.9375 \mu \mathrm{g} / \mathrm{ml}$ \\
\hline ClAuNP's & $12.5 \mu \mathrm{g} / \mathrm{ml}$ \\
\hline BTAuNP's & $1.875 \mu \mathrm{g} / \mathrm{ml}$ \\
\hline CoAuNP's & $0.46875 \mu \mathrm{g} / \mathrm{ml}$ \\
\hline AHAuNP's & $50 \mu \mathrm{g} / \mathrm{ml}$ \\
\hline MEAuNP's & $0.46875 \mu \mathrm{g} / \mathrm{ml}$ \\
\hline MAAuNP's & $3.75 \mu \mathrm{g} / \mathrm{ml}$ \\
\hline PAAuNP's & $0.46875 \mu \mathrm{g} / \mathrm{ml}$ \\
\hline
\end{tabular}

Note: These results indicate that the gold nanoparticles have good capabilities for anti-bacterial activity against the tested bacterial strains. Hence, these gold nanoparticles can be further exploited and employed as efficient anti-microbial agents.

Table 7: MIC studies of $V$. cholerae Vs 8 AuNP's.

\begin{tabular}{|l|l|}
\hline GTAuNP's & $1.875 \mu \mathrm{g} / \mathrm{ml}$ \\
\hline ClAuNP's & $50 \mu \mathrm{g} / \mathrm{ml}$ \\
\hline BTAuNP's & $1.875 \mu \mathrm{g} / \mathrm{ml}$ \\
\hline CoAuNP's & $12.5 \mu \mathrm{g} / \mathrm{ml}$ \\
\hline AHAuNP's & $50 \mu \mathrm{g} / \mathrm{ml}$ \\
\hline MEAuNP's & $1.875 \mu \mathrm{g} / \mathrm{ml}$ \\
\hline MAAuNP's & $50 \mu \mathrm{g} / \mathrm{ml}$ \\
\hline PAAuNP's & $0.9375 \mu \mathrm{g} / \mathrm{ml}$ \\
\hline
\end{tabular}

Table 8: \%entrapment efficiency.

\begin{tabular}{|l|l|l|}
\hline S.No. & AuNP's studied & \%Entrapment Efficiency \\
\hline 1. & Camellia sinensis AuNP's & 89.2 \\
\hline 2. & Syzygium aromaticum AuNP's & 88.8 \\
\hline 3. & Coriandrum sativum AuNP's & 96.8 \\
\hline
\end{tabular}

\section{In vitro drug release}

The in vitro studies were carried out in phosphate buffer saline at $\mathrm{pH}$ 7.4. It was observed that release of insulin from gold nanoparticles was about $89 \%$ in 24 hours. The observed results imply a sustained release of insulin from the gold nanoparticles. These results suggest that gold nanoparticles can be used as a drug carrier for larger biomolecules.

\section{Conclusion}

The nanoparticles were investigated for their various applications like Antimicrobial activity against strains of bacteria using well diffusion methods and MIC studies. The drug loading capacity /drug intake along with in vitro drug release were studied with peptide hormone insulin. The role of gold nanoparticles in water purification system was as well demonstrated. The anticoagulant property of gold nanoparticles was examined. It is thereby concluded that the synthesized gold nanoparticles have a wide range of applications in diversified approaches.

\section{References}

1. Kamala Priya MR, Priya R Iyer. Extracellular rapid biosynthesis of gold nanoparticles using various green extracts of plants, International journal of molecular biology \& biochemistry. 2014;2(1):33-40.

2. Ahmad A, Mukherjee P, Senapati S, Mandal D, Islam Khan, Kumar R, et al. Extracellular biosynthesis of silver nanoparticles using the fungus Fusarium oxysporum. 2003;28(4): 313-318.

3. Chandran SP, Chaudhary M, Pasricha R, Ahmad A, Sastry M. Synthesis of gold nanotriangles and silver nanoparticles using Aloe vera plant extract, Biotechnology Prog. 2006;22(2): 577-583.

4. Sumit S Lal, PL Nayak. Green Synthesis of Gold Nanoparticles using Various Extract of Plants and Spices. International Journal of Science Innovations and Discoveries. 2012;2(3).

5. Z Sadowski, IH Maliszewska, B Grochowalska, I Polowczyk T Koźlecki. Synthesis of silver nanoparticles using microorganisms, Materials Science-Poland. 2008;26(2): 419-424.

6. Bar H, Bhui DK, Sahoo PG, Sarkar P, Sankar PD, Misra A. Green synthesis of silver nanoparticles using latex of Jatrapha curcas, Colloids Surf A Physicochem Eng Asp. 2009;339:134-139.

7. Begum NA, Mondal S, Basu S, Laskar AR, Mandal D. Biogenic synthesis of $\mathrm{Au}$ and $\mathrm{Ag}$ nanoparticles using aqueous solutions of Black Tea leaf extracts. Colloids Surf B Biointerfaces. 2009;71(1):496-502. doi: 10.1016/j.colsurfb.2009.01.012.

8. Kamala Priya MR and Priya R Iyer. Comparative study on the characterization of gold nanoparticles synthesized using various plant extracts. International Journal of Phytotherapy. 2015;5(1):17-21.

9. Annamalai A, Sarah Thomas Babu, Niji AJ, Sudha D and Christina VL. 2011 Biosynthesis and Characterisatiion of Silver and Gold nanoparticles using aqueous leaf extracts of Phyllanthus amarus Schum. \&Thonn. World applied sciences Journal 13 (8): 1833-1840.

10. Priya RI and Kamala Priya MR, Studies on the various parameters underlying the Synthesis of nanoparticles and the in-vitro stability of nanoparticles, Frontiers in Biotechnology. 2014;1(1).

11. Ghosh P, Han G, De M, Kim KC, Rotello MV. Gold nanoparticles in delivery applications. Advanced Drug Delivery Reviews. 2008;60:1307-1315.

12. Kamala Priya MR, Priya RI. Anticancer studies of the synthesized gold nanoparticles against MCF 7 breast cancer cell lines. Applied Nanoscience. 2015;5(4):443-448.

13. Cai W, Gao T, Hong H, Sun J. Application of gold nanoparticles in cancer nanotechnology. Nanotechnol Sci Appl. Cancer Letters. 2008(1). doi: 10.2147/NSA.S3788.

14.Pal S, Tak YK, Song JM. Does the Antibacterial Activity of Silver Nanoparticles Depend on the Shape of the Nanoparticle? A Study of the Gram-Negative Bacterium Escherichia coli. Appl Environ Microbiol. 2007;73(6):1712-1720. 